\title{
The Link between Periodontal Disease and Oral Cancer-A Certainty or a Never-Ending Dilemma?
}

\author{
Zinovia Surlari, Dragoș Ioan Virvescu ${ }^{\dagger}$, Elena-Raluca Baciu ${ }^{*}$, Roxana-Ionela Vasluianu * \\ and Dana Gabriela Budală
}

Citation: Surlari, Z.; Virvescu, D.I.; Baciu, E.-R.; Vasluianu, R.-I.; Budală, D.G. The Link between Periodontal Disease and Oral Cancer-A Certainty or a Never-Ending Dilemma?. Appl. Sci. 2021, 11, 12100. https://doi.org/ 10.3390/app112412100

Academic Editor: Ionut Luchian

Received: 9 November 2021

Accepted: 16 December 2021

Published: 19 December 2021

Publisher's Note: MDPI stays neutral with regard to jurisdictional claims in published maps and institutional affiliations.

Copyright: (c) 2021 by the authors. Licensee MDPI, Basel, Switzerland. This article is an open access article distributed under the terms and conditions of the Creative Commons Attribution (CC BY) license (https:// creativecommons.org/licenses/by/ $4.0 /)$.
Faculty of Dental Medicine, “Grigore T. Popa” University of Medicine and Pharmacy, 700115 Iasi, Romania; zinovia.surlari@umfiasi.ro (Z.S.); dragos.virvescu@umfiasi.ro (D.I.V.);

dana-gabriela.bosinceanu@umfiasi.ro (D.G.B.)

* Correspondence: elena.baciu@umfiasi.ro (E.-R.B.); roxana.vasluianu@umfiasi.ro (R.-I.V.)

+ Author with equal contribution as the first author.

\begin{abstract}
Periodontal disease can have a substantial systemic influence on the body that extends beyond the oral cavity and can lead to local inflammation, bone damage, and tooth loss. A great number of studies suggest that periodontitis and oral cancer are linked, however it is unclear if specific periodontal bacteria promote the development of systemic illness. The mediators of the relationship between those two pathologies are still being discovered, but the research findings indicate the existence of a correlation. Additional research, including confounding factors, is needed to strengthen this link.
\end{abstract}

Keywords: periodontal disease; oral cancer; tooth loss

\section{Introduction}

Periodontal disease (PD) is a chronic inflammatory disorder [1] that affects the supporting structures of the tooth, resulting in the loss of periodontal support tissues, increased tooth mobility, and possibly the loss of teeth [2]. Gingival tissue injury is determined by an imbalance between a localized infection and an excessive host inflammatory response [3,4]. According to new findings, the effects of PD may not be restricted to the oral cavity but may even have systemic ramifications [5-7]. Indeed, PD has been linked to a mild inflammatory response throughout the body. Although the mechanisms underlying this link are unknown, PD could be a distant source of low-grade systemic inflammation [8]. Numerous studies published in the last three decades have shown a favorable or negative association between periodontal disease and numerous diseases and solid neoplasms [9-11].

A positive correlation, as opposed to a negative one or even no correlation, demonstrates a strong justification for the link based on the research findings. Following this idea, several studies looking at specific types of malignancies, as well as the overall total cancer rate and its relationship with periodontal disease, have lately shown a correlation between periodontal disease and cancer [12-14]. The claimed link is based on the fact that inflammation is a prominent factor in both periodontal disease and cancer.

We designed a review of the relevant literature conducted on Pub Med and Web of Science using the following search terms: "periodontitis," "tooth loss," and "periodontal disease," in combination with "cancer" and "oral cancer". The aim was to highlight a possible link between periodontal disease and oral cancer as well as the existence of potential disruptive factors that could invalidate the results of the studies.

\section{Periodontal Disease Etiopathogenesis}

Periodontal disease has been reported since ancient times [15], becoming one of the most frequent oral diseases and affecting people of all ages and genders in many parts of the world [16]. PD is an extremely common condition with very large variations from 
one country to another $[17,18]$. As the world's population ages, periodontal disease has become a serious public health concern according to the US Centers for Disease Control and Prevention, and can cause speech impairment, low self-esteem, and a lower quality of life $[19,20]$.

Clinical studies conducted by Gjermo et al. on the association of marginal periodontal disease with age estimated that $15 \%$ of people between the ages of 31 and 50 years and $30 \%$ of those over 50 years develop severe chronic marginal periodontitis [21].

Lakhssassi and Sixou mentioned in their study that $20 \%$ of the population of France aged between 35 and 65 years is affected by chronic marginal periodontitis [22]. In the United States, more than half of the 18-year-old population has an incipient form of periodontal disease and $75 \%$ of the population over 35 years have various forms of periodontal disease [23]. The severity of periodontal disease is also variable. According to some studies, between $30 \%$ and $50 \%$ of these diseases are mild, and $5-15 \%$ are severe and generalized [24,25].

Many etiologic factors have been attributed to periodontal disease, both local and general. Given this, the following factors were incriminated: dental biofilm, surface morphological changes of the teeth, dental arches or temporomandibular joint (TMJ) disorders, occlusal and muscular condition, and general systemic factors. Following significant research, it has been discovered that the microbial component plays the most important role in the development of periodontal disease in its destructive form, with the other factors being favorable or predisposing [26].

The microbial etiology of periodontal disease is unanimously accepted today, but of the more than 500 microbial species that can form the bacterial biofilm, only a small part are involved in the pathogenesis of periodontal disease [27]. Thus, the presence in the bacterial biofilm of certain specific microorganisms, which can produce substances with a destructive role for periodontal tissues, is one of the necessary conditions for the development of periodontal disease. By histological investigation, Page and Schroeder observed activation of the acquired immune system, which includes T cells and B cells, in periodontitis-affected donors in 1976 [28]. Since the 1990s, advances in molecular biology have uncovered a variety of molecular processes underpinning periodontitis pathogenesis. Page and Kornman discussed the link between periodontal bacteria and the host response, as well as the creation of different mediators during inflammation and periodontal tissue death [29].

Current data suggest that a small group of predominantly Gram-negative anaerobic or microaerophilic bacteria in the biofilm are frequently associated with initiation and progression of PD. Organisms strongly involved as etiological agents include Porphyromonas gingivalis (P. gingivalis), Aggregatibacter actinomycetemcomitans (A. actinomycetemcomitans) and Tannerella forsythia (T. forsythia) [30]. The bacterial aggression represented by antigens, lipopolysaccharides, and other virulence factors stimulates the host response, which consists of gum-limited disease (gingivitis) or the onset of periodontitis. The oral microbiota and other physical stimuli produced by mastication are continuously acting on the periodontal tissue. Under physiological settings, there is a delicate balance between the local immune response and the microbiota [31]. When all elements of the microbiota are altered after colonization by a "keystone" pathogen such as P. gingivalis, the pathogenicity of the entire community is elevated, and the tissue homeostasis is altered. Bacterial cells play a role in the pathogenesis of periodontitis through exotoxins, enzymes, and metabolites, of which exotoxins and leukotoxins intervene in polymorphonuclear leukocytes (PMN), destroy the leukocytes in the gingival groove, and cause colonization and invasion of the periodontal tissue [30,32]. Gingival connective tissue, periodontal ligament, and alveolar bone are all destroyed by inflammatory mediators. The loss of the outer cementoblast layer produces root surface changes, resulting in superficial cement resorption lesions. Endotoxins, which are produced by bacteria, irritate soft tissue and impede the activation of healing mechanisms $[33,34]$. 
Specific and non-specific immunity complement each other. The inflammation that remains limited at the gingival level is the result of a balanced symbiosis between the biofilm and the host tissues, and the development of PD is the result of the imbalance of such symbiosis, which is modified by the environment and genetic factors. Pro-inflammatory cytokines are those produced during an inflammatory response and promote its progression, such as interleukin-1 (IL-1), IL-6, IL-8, tumor necrosis factor- $\alpha$ (TNF- $\alpha$ ), IL-12, IL-18, interferons (IFN), and macrophage granulocytes [35,36].

Anti-inflammatory cytokines inhibit the inflammatory process by their ability to suppress gene expression for pro-inflammatory cytokines and inhibit the effects of inflammatory mediators IL-4, IL-10, IL-13, IL-16, and transforming growth factor (TGF) [37,38]. Activation of the biochemical mechanisms of cytokine secretion targets the signaling mechanisms due to interference between the associated microbial molecular pattern (lipopolysaccharides, fimbriae) and the pattern of receptor recognition (toll-like receptors, nucleotidebinding, and oligomerization domain-like receptors) that exist in cells in the periodontal tissues and in infiltrated leukocytes. Existing studies point to the importance of a large number of cytokines in initiating and regulating immune responses in periodontitis, as well as in tissue destruction, by mainly activating the matrix metalloproteinases (MMP) [39,40].

Saliva contains many antibacterial factors [41,42] such as lysozyme, lactoferrin, and he peroxidase system, but these do not play a significant role in protection against periodontal disease $[43,44]$. Initially, the liquid gingival works by washing non-stick biofilm bacteria and reduces the diffusion of bacterial metabolites to tissues by diluting them [45,46]. The complement in the gingival fluid is activated by opsonized bacteria, their metabolic products, and by the bacterial endotoxins released [47].

The activated complement can cause lysis or inhibition of a number of bacteria and is involved in bacterial phagocytosis by neutrophils and macrophages. It can also participate in cellular distinctions through its C3a and C5a components, causing the release of histamine from mast cells, as well as other chemotactic factors and several cytokines from periodontal tissue [48].

\section{Periodontal Disease and Systemic Disorders}

Although periodontal disease has a local area of manifestation, multiple interferences are known with the general condition for an organism. From this perspective, it must be viewed as a complex pathological process that can only be treated with a combination of medical, surgical, local, and general therapeutic methods. For these reasons, Preshaw et al. proposed a new concept in periodontal therapy that must be considered a combination of antibacterial treatment of the periodontal disease and therapeutic methods to modulate the body's response $[49,50]$.

The link between oral disease and general health is not a novel concept. The function of oral infection and inflammation in contributing to disorders in other parts of the body has been investigated and reported for ages. Hippocrates, in ancient Greece, healed two patients suffering from discomfort from TMJ disorders by teeth extractions.

From 1912 to roughly 1950, we lived in the era of "focal infection," which dominated our thoughts. The "focal infection theory" is a historical concept based on the assumption that some infections may cause chronic and acute diseases in different areas of the body. It was extremely popular from 1930 to 1950 when extensive surgical procedures were carried out with the intention of eliminating all infection sources. The pathogens involved in periodontal disease can migrate, develop, and cause various systemic illnesses, including cardiovascular, respiratory, and metabolic (i.e., diabetes and osteoporosis) diseases [51]. Individuals coming to the emergency room with a myocardial infarction were overwhelmingly likely to have periodontal disease, according to Mattila and his colleagues [52].

Around 400 to 700 species have been found, and certain commensal bacteria may evolve, into "opportunistic" species, with some of them being strictly considered as pathogens. It is feasible to speculate that they may play a role in local or systemic illnesses [53]. Even while it is common to perceive periodontitis as having potentially 
detrimental effects on the body, the exact contribution of periodontitis to the etiology and progression of systemic disorders is not well understood today, but scientists supposed that periodontitis and systemic disorders have a close link, which leads to an intensification of the inflammatory response and an altered immunological response [54].

Advanced periodontal disease can have a substantial systemic influence on the body, extending beyond the oral cavity due to local inflammation, bone degradation, and tooth loss [55]. Recent advancements in detecting and measuring bacteria using new sequencing methodologies (e.g., metagenomics) have opened up new possibilities for research into the function of the microbiota in cancer formation [56-58]. There are over 57 systemic disorders that are thought to be linked to periodontal diseases, indicating that the links are established through a shared pathogenic process [59].

Figure 1 shows an association between oral cavity pathogens and general diseases [60].

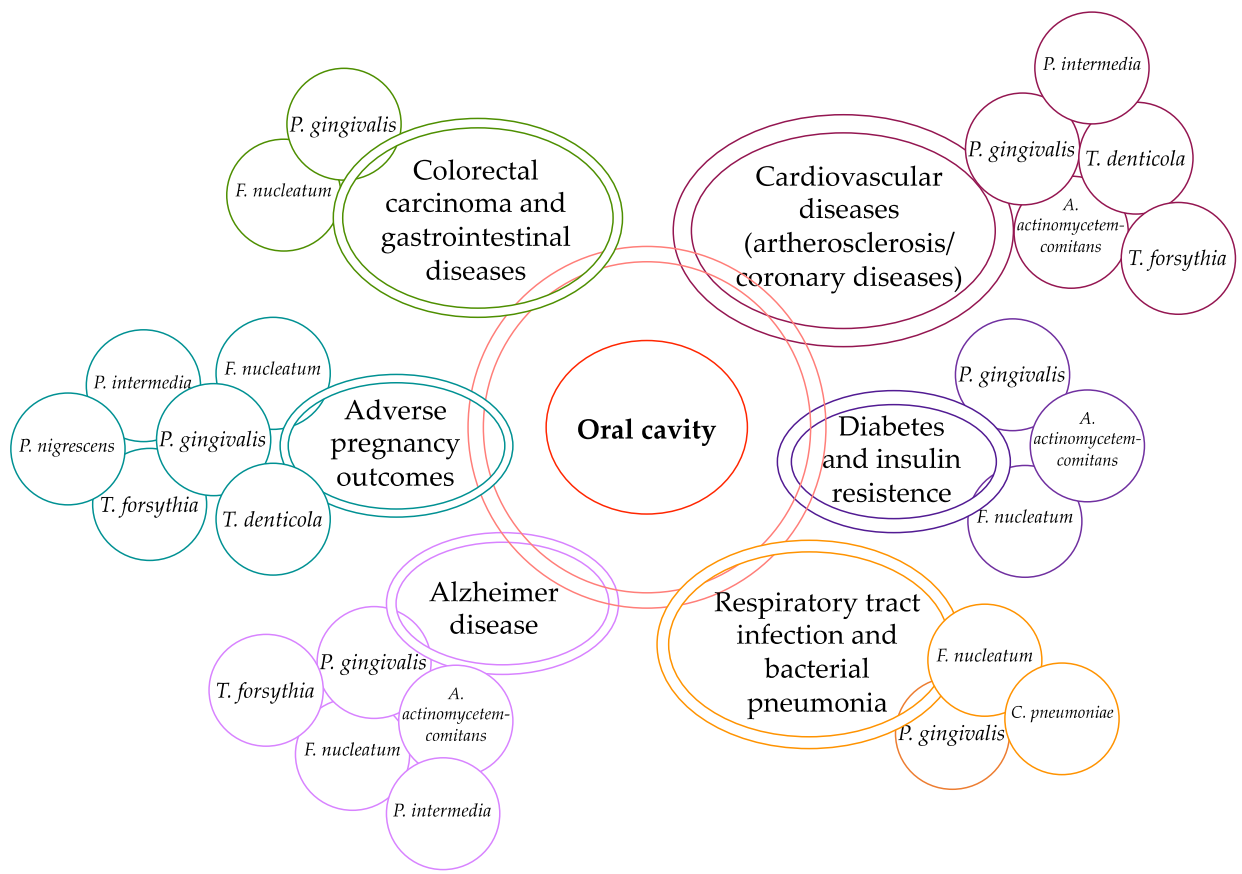

Figure 1. Schematic representation of different systemic diseases and their association with periodontal pathogens.

Despite the fact that diabetes mellitus increases the risk of periodontal disease, epidemiological studies demonstrate that people with well-controlled diabetes have periodontal problems similar to those reported in the healthy population [61]. Periodontal disease and diabetes mellitus were described as a two-way interaction in a work by Grossi and Genco [62]. Several randomized control trials, as well as a number of longitudinal and observational investigations, have offered data to back up the idea that periodontitis can have a negative impact on glycemic control [63].

Following the same path, periodontal disease was also associated with respiratory infections. In 2006, Azarpazhooh and Leake presented a review paper about the etiological relationship between oral health and pneumonia or other respiratory disorders [64]. The authors came to the conclusion that there is reasonable evidence of a link between them.

Other studies, especially longitudinal studies, postulated that osteoporosis causes bone to be more susceptible to resorption, and the inflammatory response can reduce the patient's alveolar bone mass [65].

According to an epidemiological study in molecular pathology, there is a substantial relationship between the oral microbiome and tumor incidence. Microbes have long been overlooked as a cause of cancer until key studies in the early 1990s identified Helicobacter pylori (H. Pylori) as a causal agent of stomach cancer [66]. As a result, the role of infec- 
tious agents as key contributors to the development of stomach cancer has undergone a paradigm shift.

An interesting approach established a possible relationship between periodontal diseases and the risk of various cancers, particularly hematological, breast, and prostate cancers [67], while others have found a link between periodontal disease and the risk of oral, lung, and pancreatic [68] or colorectal cancers [11]—suggesting that periodontal disease treatment and prevention could be useful in cancer prevention strategies [69]. The results of several epidemiologic studies have also suggested a possible positive association between periodontal disease and cancer risk in the different tissues [70,71].

The National Health and Nutrition Examination Survey (NHANES) I Epidemiologic Follow-up Study [72], the NHANES III study, and the Women's Health Initiative (WHI) study [73], all prospective cohort studies including data on periodontal disease, have found positive relationships between periodontitis and malignancies, including pancreatic, lung, and oro-digestive cancers.

\section{Periodontal Disease and Oral Cancer}

\subsection{Oral Cancer}

Five percent of all malignancies are head and neck cancers, with half of them occurring in the oral cavity [74]. Oral cancer is a type of malignant neoplasia that develops on the lips or in the mouth. Squamous cell cancer is the standard definition. Despite all the advanced techniques that have emerged in recent years, such as adjuvant radiotherapy and chemotherapy, the global prevalence of squamous cell cancer appears to be growing and the overall survival rate for 5 years remains low-between 50-60\% [75].

Oral cancer is a major public health issue that can affect anyone. It is among the top ten cancers in terms of incidence, and despite advances in research and therapy, survival has remained stagnant in recent years, posing a constant challenge for biomedical science.

Oral cancer is two to three times more prevalent in men than women. In worldwide reports, cancers of all regions of the oral cavity and pharynx are grouped and collectively represent as the sixth most common cancer in the world [76]. Oral cancer is a preventable disease in which significant risk factors such as smoking and drinking are present in $90 \%$ of cases [77], resulting in a synergistic impact [78].

According to the International Agency for Research on Cancer's recent studies on oral cancer, which affects the lips, tongue, gingiva, mouth floor, and salivary glands, has increased with over 300,000 cases diagnosed and 145,000 deaths per year.

Oral carcinogenesis is a multifactorial, complex process that happens when epithelial cells are influenced by multiple genetic changes. Although cancer has been known for a long time, it is only in recent years that the mechanisms of cancer onset and evolution have begun to be figured out in more depth. As early as 150 years ago, Rudolf Wirckow, the founder of cellular pathology, showed that cellular hyperplasia occurs in cancer, and is characterized by an abnormally large increase in the number of cells whose division has spiraled out of control [79]. Oral carcinogenesis is thought to begin with the transformation of a small number of normal keratinocytes.

Changes in cytogenetics and epigenetic mechanisms can also contribute to this transition. These changes can affect the cell cycle, DNA repair processes, and cell differentiation. Risk factors can be added to these changes, resulting in an unstable keratinocyte, which eventually transforms into a pre-cancerization field-causing malignant neoplastic alterations [80].

Overexpression of cytokines, produced by oral squamous cell cancer (OSCC), suppresses the adaptive immune response via T-cell mediated apoptosis and changes in the antigen processing machinery [81].

Oral cancer begins with non-aberrant keratinocytes exposed to a stimulus that disrupts their homeostasis over time, leading to epithelial hyperplasia, dysplasia in different degrees, carcinoma in situ, and the last stage, an invasive carcinoma. According to statistics, the 
tongue (ventral-lateral edge, $40 \%$ of cases), the floor of the mouth ( $30 \%$ of cases), and the lower lip are the most prevalent sites for oral cancer presentation [82].

Diagnostic markers have recently been the subject of clinical and experimental research. A diagnostic cancer marker can be specific to the stage, tissue, relapse, follow-up, or age, and it can appear at any point during the progression of cancer. Despite attempts to define cancer biomarkers, there has yet to be a consensus. Among the laboratory tests available, liquid biopsy is a less invasive approach that eliminates the need for tissue collection. Blood is currently the most common liquid biopsy. For a liquid biopsy, approximately 5 to $10 \mathrm{~mL}$ of blood is required. However, more recent research has focused on innovative and noninvasive technologies involving human saliva sampling, such as proteomic analysis, for diagnosing and understanding the OSCC genetic architecture [83].

\subsection{Hypotheses for Etiology of a Link between Periodontal Disease and Oral Cancer}

Periodontal disease can be a symptom of an underlying immune system problem or a direct cause of cancer [60]. Periodontal disease may potentially be a good indicator of a vulnerable immune system, or it may directly influence cancer risk due to inflammatory loading $[84,85]$. There are several probable explanations for the relationship between periodontitis and cancer.

The oral microbiota is crucial to the human microbiome and the body's overall health, and oral and systemic illnesses, as well as chronic inflammation, can result from microbial imbalances with their hosts [86]. Periodontal pathogens can cause chronic inflammation, which promotes already begun cells and results in a breakdown of normal cell growth control and the possibility of carcinogenesis.

Oral cancer progression has been shown to be aided by direct contacts with oral epithelial cells by Fusobacterium nucleatum (F. nucleatum), a known pathogenic oral species that demonstrated a $5.88 \%$ increase in cancer lesions [87]. Zhang et al. demonstrated that in cancer lesions there were ten species that had significantly higher abundances [88]. These species included Fusobacterium nucleatum, Prevotella intermedia, Aggregatibacter segnis, Peptostreptococcus stomatis and Catonella morbi, all of which live in the oral mucosa as commensals but can became opportunistic in certain situations related to oral cancer.

Many viruses, like human cytomegalovirus and the carcinogenic Epstein-Barr virus, have been found in periodontal diseases and are considered to be linked to cancer, including lymphoma and nasopharyngeal carcinoma. There's also some indication that certain strains of candidiasis are more common in oral cancer patients [89].

Chronic periodontal disease can indicate that a person's immune system is unable to eliminate infection and, as a result, is unable to detect tumor progression.

Periodontitis could be a sign of a certain sort of immune function that influences tumor growth and progression.

Chronic periodontal inflammation has been shown to induce genetic damage by the generation of oxidizing chemicals, like reactive oxygen and nitrogen species, which have been linked to an increased cancer risk.

Pro-inflammatory plasma cytokines, peripheral white blood cells, prostanoids, proteases-including matrix metalloproteinases_-and acute-phase proteins are examples of inflammatory indicators produced in the immunological response to periodontal disease [90].

Another potential explanation for the reported findings is the increased formation of carcinogenic nitrosamines. Poor oral hygiene, periodontal disease, cigarette use, and certain dietary variables all stimulate the generation of endogenous nitrosamines in the oral cavity by nitrate-reducing bacteria [91].

Essential mechanisms that control the periodontal inflammatory response fail.

In the 19th century, Rudolf Virchow was the first to suggest a relationship between inflammation and cancer. He observed leukocyte infiltration in the tumor microenvironment and hypothesized that persistent inflammation may be a factor in cancer progression [79].

Figure 2 summarizes all the above hypotheses [79,86-91]. 


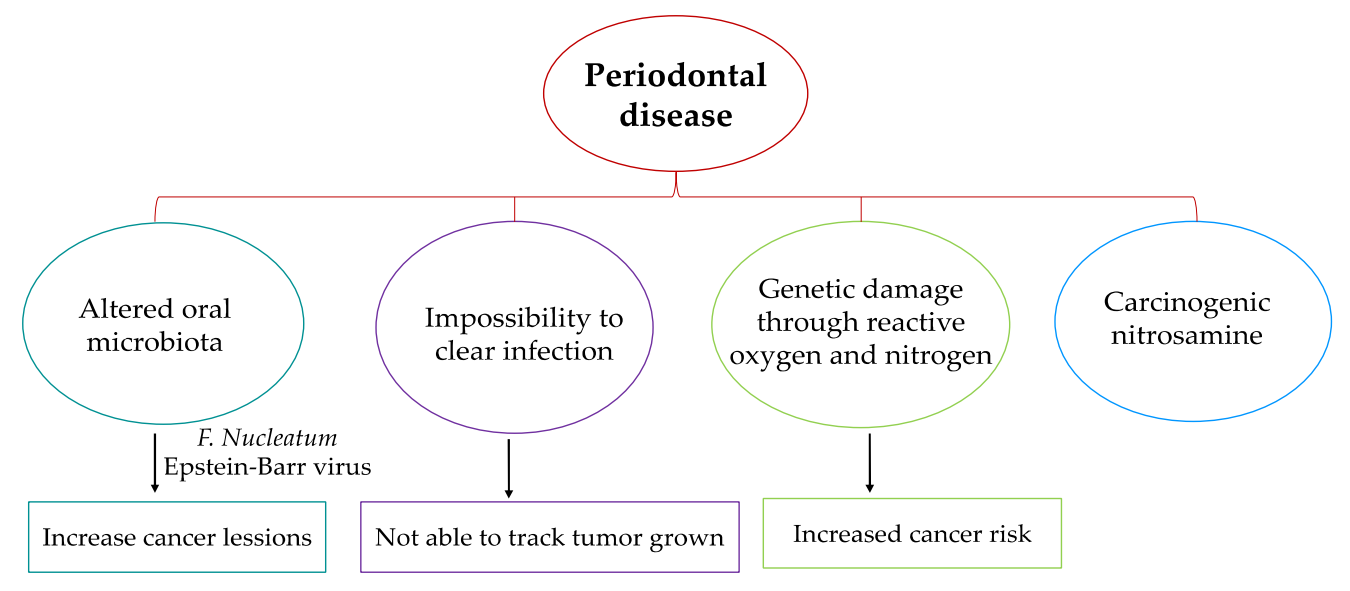

Figure 2. Schematic representation of potential processes involved in the periodontal disease-oral cancer connection.

\subsection{The Link between Periodontal Disease and Oral Cancer-Current Vision}

Poor oral hygiene [92], poor dentition, periodontal disease [93], and missing teeth or denture use [94] have all been proposed as risk factors from the earliest case-control studies on oral cancer $[95,96]$.

The main challenge with cancer, as with heart disease, is determining whether or not the connections are causal. Prospective cohort studies with extensive follow-ups can begin to address causality since exposure is determined many years before cancer diagnosis.

Bundgaard. T et al. [97] proved that tobacco and alcohol use contribute significantly to the risk of developing oral cancer. There were no significant differences between the risk estimates for the two genders or young and old persons. De Rezende et al. indicated that there is an association between cancer and more severe periodontal disease regardless of oral hygiene and dental health status [98].

Guha et al. noted that periodontal disease (as indicated by poor condition of the mouth and missing teeth) and daily mouthwash use may be independent causes of cancers [99].

Hiraki et al. showed a significant positive association between tooth loss and the risk of head and neck cancers after adjustment for potential confounding factors [100]. The findings indicate that preventive efforts aimed at the preservation of teeth may decrease the risk of these cancers.

Oral squamous cell carcinomas are among the most common cancers in southeast Asia, and more so in the Indian subcontinent. Mahtur et al. found that $P$. gingivalis, one of the most common bacteria responsible for acute periodontitis, has been linked to the invasion and spread of highly invasive oral cavity malignancies [101]. By activating promatrix metalloproteinase [102,103], as well as anergy and death of activated T cells [94,104], $P$. gingivalis aids in cancer growth and metastasis.

Squamous cell carcinoma is prevalent in northeastern Iran, with one of the highest incidences in the world. Sepehr et al. concluded, in agreement with two other previous studies, that poor oral health and periodontal disease are risk factors for squamous cell carcinoma [105].

Michaud et al. proved that periodontal disease was associated with a small, but significant, increase in overall cancer risk, which persisted in non-smokers [12].

Bacteria found in the mouth are quite complex. The significance of the oral microbiota in in-situ or distant tumor growth has gotten a lot of attention.

Following investigations, the global risk of malignancies caused by microbial infections was estimated to be $16.1 \%$, emphasizing the importance of the microbiota [106]. These findings have thrown light on continuing research in the field, reinforcing the view that oral microbiota might play a significant role in cancer through many ways, and that a complete understanding of these mechanisms can aid in tumor resistance. 
Carcinogenesis has been linked to a large range of oral microorganisms. F. nucleatum and $P$. gingivalis are two such that have been linked to the progression of different cancers. Bioinformatic prediction analysis of sequencing data revealed a high abundance of the $F$. nucleatum subspecies Polymorphum in oral cancer tissues during in situ oral squamous cell carcinoma [107].

F. nucleatum was found in squamous cell carcinoma when quantitative polymerase chain reaction (qPCR) was used to determine its DNA content [108]. The relative abundance of $F$. nucleatum had a negative connection with cancer-specific survival, implying that $F$. nucleatum is only a predictive biomarker.

P. gingivalis has lately been thought to have a role in the development of cancers due to its ability to disrupt epithelial tissues and host defense mechanisms [109]. Since the oro-digestive tract is a continuous smooth tube, P. gingivalis, which has more mobility and invasion skills than other oral bacteria, might potentially disseminate across the area and speed up the in-situ carcinogenesis process. With the passage of food and water, P. gingivalis can easily move from the mouth cavity to other parts of the oro-digestive tract.

A clinical study has validated a link between oral bacteria and squamous cell carcinoma, finding that greater levels of $P$. gingivalis were linked to a higher incidence of squamous cell carcinoma [110]. When comparing squamous cell cancer tissues to the adjacent or normal tissues, the intensity of positive immunohistochemistry staining for P. gingivalis was substantially higher in the squamous cell carcinoma tissues, indicating a probable link between $P$. gingivalis and squamous cell carcinoma patients who had greater median serum levels of $P$. gingivalis immunoglobulin G (Ig G) and IgA than the controls [111,112].

P. gingivalis penetrates the oral mucosa by targeting Grainyhead-like 2 (GRHL2), an epithelium specific transcription factor, according to a recent study [113]. Later, GRHL2 damages the epithelial barrier by inhibiting the production of tight junction proteins, resulting in greater periodontal tissue loss. Furthermore, $P$. gingivalis stimulates the production of cytokines like interleukina-6 (IL-6), which activate tumor-promoting transcription factors like STAT1. P. gingivalis can also create a microenvironment by targeting the cluster of differentiation 274 (CD274) and programmed cell death 1 ligand 2 (PDCD1LG2) through STATI 1 activation [114].

P. gingivalis also causes the proenzyme matrix metalloproteinase 9 (proMMP9) to be expressed, and then the active form of the salivary matrix metalloproteinase 9 (MMP-9) to be produced. MMP-9 is thought to play a major role in the defacement of the tumor microenvironment, which supports cancer cell invasion and metastasis [102].

C-reactive protein (CRP) levels in the blood are linked to P. gingivalis (CRP). CRP opsonizes $P$. gingivalis for complement-binding and activates the complement, according to studies [115]. The link between high levels of CRP in the blood and an elevated risk of epithelial malignancies has been established [116].

Table 1 shows the mechanisms by which $P$. gingivalis may promote oral cancer.

Table 1. Possible mechanism for P.gingivalis promoting oral cancer.

\begin{tabular}{lc} 
& Mechanisms \\
\cline { 2 - 3 } $\begin{array}{l}\text { P. gingivalis promoting oral cancer } \\
\text { Activation of immunologic and inflammatory reactions via IL-1, IL-6, IL-8, TNF- } \alpha \\
\text { Creating favorable microenvironment via PDCD1LG2 } \\
\text { Degaradation of tumor microenvironment via MMP9 }\end{array}$ \\
Opsonization of bacteria for complement-binding and activation of complement (CRP) \\
\hline
\end{tabular}

Researchers demonstrated through studies that relied on bacterial cultures and biochemical analysis that Gram-negative anaerobes (Fusobacterium spp., Prevotella spp., etc.) were present more frequently on the tumor surface of OSCC [73]. 
Other studies have reported that F. nucleatum, Pseudomonas aeruginosa (P. aeruginosa) [117], and Fusobacterium periodonticum (F. periodonticum) are associated with OSCC development [107].

\subsection{Potential Confounding Factors of the Periodontal Disease and Oral Cancer Link}

Periodontal disease is linked to smoking, which is a major modifiable risk factor. Smoking is linked to an increased incidence of tooth loss, which may make the tooth loss-cancer link difficult to interpret [118]. It has been suggested that studies on periodontal disease and systemic diseases should be restricted to non-smokers in order to reduce the confounding influence from smoking [119].

There are other confounding factors. Changes in nutrition, such as a lower intake of fruits and vegetables, may be linked to tooth loss caused by severe periodontal disease [120]. Not adjusting for food could result in confounding for some malignancies, such as oral cancer, where fruit, vegetable, and vitamin $C$ intake is known to reduce the risk of cancer. A prospective study of nutrition in the years leading up to a periodontal disease diagnosis may aid in determining the direction of the link.

\section{Conclusions}

According to the literature on the selected topic, there is a correlation between periodontal disease and oral cancer. Cancer patients exhibited more severe periodontitis but further longitudinal studies - comprising of periodontitis staging, nutritional conditions, and lifestyles - should be conducted in order to validate this link and better understand the role of periodontal disease in oral carcinogenesis.

Possible biologic processes can be further investigated as the function of periodontal disease in the etiology of oral malignancies. Periodontal disease can be a symptom of an underlying immune system problem or a direct cause of cancer.

Periodontal disease may also be a good indicator of an immune system that is vulnerable to infection, or it may directly affect cancer risk due to inflammatory processes. As a future concern, we should investigate the nature of this relationship. This could include a more frequent periodontal reminder schedule to keep disease and inflammation to a minimum, as well as emphasizing the need for regular dental checkups, and the need for meticulous oral care.

Finally, based on the evidence to date, it would be helpful for dental professionals to be aware of the real possibility that periodontal disease could be a risk factor for cancer.

Author Contributions: Conceptualization, D.G.B., Z.S. and D.I.V.; methodology, D.G.B., Z.S. and D.I.V.; investigation, D.G.B., Z.S. and D.I.V.; resources, D.G.B., Z.S. and D.I.V.; writing-review and editing, D.G.B., E.-R.B. and R.-I.V.; visualization D.G.B., E.-R.B. and R.-I.V.; supervision, E.-R.B. and R.-I.V. All authors read and agreed to the published version of the manuscript.

Funding: This research received no external funding.

Institutional Review Board Statement: Not applicable.

Informed Consent Statement: Not applicable.

Data Availability Statement: Not applicable.

Conflicts of Interest: The authors declare no conflict of interest.

\section{References}

1. Usui, M.; Onizuka, S.; Sato, T.; Kokabu, S.; Ariyoshi, W.; Nakashima, K. Mechanism of alveolar bone destruction in periodontitis-Periodontal bacteria and inflammation. Jpn. Dent. Sci. Rev. 2021, 57, 201-208. [CrossRef] [PubMed]

2. Könönen, E.; Gursoy, M.; Gursoy, U.K. Periodontitis: A multifaceted disease of tooth-supporting tissues. J. Clin. Med. 2019, 8, 1135. [CrossRef]

3. Gao, L.; Kang, M.; Zhang, M.J.; Sailani, M.R.; Kuraji, R.; Martinez, A.; Ye, C.; Kamarajan, P.; Le, C.; Zhan, L.; et al. Polymicrobial periodontal disease triggers a wide radius of effect and unique virome. NPJ Biofilms Microbiomes 2020, 6, 1-13. [CrossRef] 
4. Loesche, W.J.; Grossman, N.S. Periodontal disease as a specific, albeit chronic, infection: Diagnosis and treatment. Clin. Microbiol. Rev. 2001, 14, 727-752. [CrossRef]

5. Amar, S.; Han, X. The impact of periodontal infection on systemic diseases. Med. Sci. Monit. 2003, 9, $291-299$.

6. Oindrila, P.; Payal, A.; Michael, M.; Shampa, C. Inflammation in periodontal disease: Possible link to vascular disease. Front. Physiol. 2021, 11, 609614.

7. Salhi, L.; Rompen, E.; Sakalihasan, N.; Teughels, W.; Michel, J.B.; Lambert, F. Can Periodontitis Influence the Progression of Abdominal Aortic Aneurysm? A Systematic Review. Angiology 2019, 70, 479-491. [CrossRef]

8. Sinisalo, J.; Paronen, J.; Mattila, K.J.; Syrjala, M.; Alfthan, G.; Palosuo, T.; Nieminen, M.S.; Vaarala, O. Relation of inflammation to vascular function in patients with coronary heart disease. Atherosclerosis 2000, 149, 403-411. [CrossRef]

9. Joshipura, K.J.; Wand, H.C.; Merchant, A.T.; Rimm, E.B. Periodontal disease and biomarkers related to cardiovascular disease. J. Dent. Res. 2004, 83, 151-155. [CrossRef]

10. Di Spirito, F.; La Rocca, M.; De Bernardo, M.; Rosa, N.; Sbordone, C.; Sbordone, L. Possible association of periodontal disease and macular degeneration: A case-control study. Dent. J. 2020, 9, 1. [CrossRef] [PubMed]

11. Di Spirito, F.; Toti, P.; Pilone, V.; Carinci, F.; Lauritano, D.; Sbordone, L. The association between periodontitis and human colorectal cancer: Genetic and pathogenic linkage. Life 2020, 10, 211. [CrossRef] [PubMed]

12. Michaud, D.S.; Liu, Y.; Meyer, M.; Giovannucci, E.; Joshipura, K. Periodontal disease, tooth loss, and cancer risk in male health professionals: A prospective cohort study. Lancet Oncol. 2008, 9, 550-558. [CrossRef]

13. Abnet, C.C.; Kamangar, F.; Dawsey, S.M.; Stolzenberg-Solomon, R.Z.; Albanes, D.; Pietinen, P.; Virtamo, J.; Taylor, P.R. Tooth loss is associated with increased risk of gastric non-cardia adenocarcinoma in a cohort of Finnish smokers. Scand. J. Gastroenterol. 2005, 40, 681-687. [CrossRef]

14. Tezal, M.; Sullivan, M.A.; Reid, M.E.; Marshall, J.R.; Hyland, A.; Loree, T.; Lillis, C.; Hauck, L.; Wactawski-Wende, J.; Scannapieco, F.A. Chronic periodontitis and the risk for tongue cancer. Arch. Otolaryngol. Head Neck Surg. 2007, 133, 450-454. [CrossRef]

15. Brkic, Z.; Pavlić, V. Periodontology: The historical outline from ancient times until the 20th Century. Vojnosanit. Pregl. 2017, 74, 193-199. [CrossRef]

16. Billings, M.; Holtfreter, B.; Papapanou, P.N.; Mitnik, G.L.; Kocher, T.; Dye, B.A. Age-dependent distribution of periodontitis in two countries: Findings from NHANES 2009 to 2014 and SHIP-TREND 2008 to 2012. J. Periodontol. 2018, 89, 140-158. [CrossRef]

17. Raitapuro-Murray, T.; Molleson, T.I.; Hughes, F.J. The prevalence of periodontal disease in a Romano-British population c. 200-400 AD. Br. Dent. J. 2014, 217, 459-466. [CrossRef] [PubMed]

18. Nazir, M.; Al-Ansari, A.; Al-Khalifa, K.; Alhareky, M.; Gaffar, B.; Almas, K. Global prevalence of periodontal disease and lack of its surveillance. Sci. World J. 2020, 2020, 2146160. [CrossRef] [PubMed]

19. Richards, D. Oral diseases affect some 3. 9 billion people. Evid. Based Dent. 2013, 14, 35. [CrossRef] [PubMed]

20. CDC researchers find close to half of American adults have periodontitis. J. Can. Dent. Assoc. 2012, 78, c136.

21. Gjermo, P.; Rosing, C.K.; Susin, C.; Oppermann, R. Periodontal diseases in Central and South America. Periodontol. 2000 2002, $29,70-78$.

22. Van Winkelhoff, A.J.; Winkel, E.G. Antibiotics in periodontics: Right or wrong? J. Periodontol. 2009, 80, 1555-1558. [CrossRef]

23. Negrato, C.A.; Tarzia, O.; Jovanovič, L.; Chinellato, L.E.M. Periodontal disease and diabetes mellitus. J. Appl. Oral Sci. 2013, 21, 1-12. [CrossRef] [PubMed]

24. Preshaw, P.M. Detection and diagnosis of periodontal conditions amenable to prevention. BMC Oral Health 2015, 15, S5. [CrossRef]

25. Tonetti, M.S.; Greenwell, H.; Kornman, K.S. Staging and grading of periodontitis: Framework and proposal of a new classification and case definition. J. Periodontol. 2018, 89, 159-172. [CrossRef]

26. Saglie, F.R.; Caranza, F.A.; Newman, M.G.; Cheng, L.; Lewin, K.J. Identification of tissue invading bacteria in human periodontal diseases. J. Periodontal Res. 1982, 17, 452-455. [CrossRef]

27. Peković, D.D.; Fillery, E.D. Identification of bacteria in immunopathological mechanisms of human periodontal diseases. J. Periodontal Res. 1984, 19, 329-351. [CrossRef]

28. Page, R.C.; Schroeder, H.E. Pathogenesis of inflammatory periodontal disease. A summary of current work. Lab. Investig. 1976, 34, 235-249. [PubMed]

29. Page, R.C.; Kornman, K.S. The pathogenesis of human periodontitis: An introduction. Periodontol. 2000 1997, 14, 9-11. [CrossRef]

30. Socransky, S.S.; Haffajee, A.D. Periodontal microbial ecology. Periodontol. 2000 2005, 38, 13-87. [CrossRef] [PubMed]

31. Listgarten, M.A. Pathogenesis of periodontitis. J. Clin. Periodontol. 1986, 13, 418-430. [CrossRef]

32. Offenbacher, S.; Heasman, P.A.; Collins, J.G. Modulation of host PGE 2 secretion as a determinant of periodontal disease expression. J. Periodontol. 1993, 64, 432-444.

33. Grau, A.J.; Becher, H.; Ziegler, C.M.; Lichy, C.; Buggle, F.; Kaiser, C.; Lutz, R.; Bültmann, S.; Preusch, M.; Dörfer, C.E. Periodontal disease as a risk factor for ischemic stroke. Stroke. Cereb. Circ. 2004, 35, 496-501. [CrossRef]

34. Nakamura, I.; Takahashi, N.; Jimi, E.; Udagawa, N.; Suda, T. Regulation of osteoclast function. Mod. Rheumatol. 2012, 22, 167-177. [CrossRef] [PubMed]

35. Bloemen, V.; Schoenmaker, T.; de Vries, T.J.; Everts, V. Direct cell-cell contact between periodontal ligament fibroblasts and osteoclast precursors synergistically increases the expression of genes related to osteoclastogenesis. J. Cell. Physiol. 2010, 222, 565-573. [CrossRef] 
36. Bloemen, V.; Schoenmaker, T.; de Vries, T.J.; Everts, V. IL-111 $\beta$ favors osteoclastogenesis via supporting human periodontal ligament fibroblasts. J. Cell. Biochem. 2011, 112, 1890-1897. [CrossRef] [PubMed]

37. Adamopoulos, I.E.; Pflanz, S. The emerging role of Interleukin 27 in inflammatory arthritis and bone destruction. Cytokine Growth Factor Rev. 2013, 24, 115-121. [CrossRef]

38. Fujihara, R.; Usui, M.; Yamamoto, G.; Nishii, K.; Tsukamoto, Y.; Okamatsu, Y.; Sato, T.; Asou, Y.; Nakashima, K.; Yamamoto, M. Tumor necrosis factor- enhances RANKL expression in gingival epithelial cells via protein kinase A signaling. J. Periodontal Res. 2014, 49, 508-517. [CrossRef]

39. Okui, T.; Aoki, Y.; Ito, H.; Honda, T.; Yamazaki, K. The presence of IL-17+/FOXP3+ double-positive cells in periodontitis. J. Dent. Res. 2012, 91, 574-579. [CrossRef]

40. Sun, Y.; Shu, R.; Li, C.L.; Zhang, M.Z. Gram-negative periodontal bacteria induce the activation of Toll-like receptors 2 and 4, and cytokine production in human periodontal ligament cells. J. Periodontol. 2010, 81, 1488-1496. [CrossRef] [PubMed]

41. Parlak, H.M.; Karaarslan, D.; Ide, S.; Çelik, H.H.; Karabulut, E.; Ertan, A.A.; Alev, F. Analysis of the nano and microstructures of the cervical cementum and saliva in periodontitis: A pilot study. J. Oral Biosci. 2021, 63, 370-377. [CrossRef]

42. Saranya, K.K.N.; Maradi, A.; Chithresan, K.; Janakiram, S.H.; Krishna, P. Molecular signatures in infrared spectra of saliva in healthy, chronic and aggressive periodontitis. Vib. Spectrosc. 2020, 111, 103179. [CrossRef]

43. Kawamoto, D.; Pontes Lucas Amado, P.; Albuquerque-Souza, E.; Bueno, M.R.; Campos Vale, G.; Saraiva, L.; Pinto Alves Mayer, M. Chemokines and cytokines profile in whole saliva of patients with periodontitis. Cytokine 2020, 135, 155197. [CrossRef] [PubMed]

44. Altin, K.T.; Topcuoglu, N.; Duman, G.; Umsal, M.; Celik, A.; Kuvvetli, S.S.; Kasikci, E.; Sahin, F.; Kulekci, G. Antibacterial effects of saliva substitutes containing lysozyme or lactoferrin against Streptococcus mutans. Arch. Oral Biol. 2021, 129, 105183. [CrossRef]

45. Huynh, N.C.; Everts, V.; Pavasant, P.; Ampornaramveth, R.S. Interleukin-1 $\beta$ induces human cementoblasts to support osteoclastogenesis. Int. J. Oral Sci. 2017, 9, e5. [CrossRef] [PubMed]

46. Meyle, J.; Chapple, I. Molecular aspects of the pathogenesis of periodontitis. Periodontol. 2000 2015, 69, 7-17. [CrossRef]

47. Nakanishi-Matsui, M.; Yano, S.; Matsumoto, N.; Futai, M. Lipopolysaccharide induces multinuclear cell from RAW 264.7 line with increased phagocytosis activity. Biochem. Biophys. Res. Commun. 2012, 425, 144-149. [CrossRef] [PubMed]

48. Liu, R.; Desta, T.; Raptis, M.; Darveau, R.P.; Graves, D.T. P. gingivalis and E. coli lipopolysaccharides exhibit different systemic but similar local induction of inflammatory markers. J. Periodontol. 2008, 79, 1241-1247.

49. Preshaw, P.M.; Hefti, A.F.; Jepsen, S. Subantimicrobial dose doxycycline as adjunctive treatment for periodontitis. A review. J. Clin. Periodontol. 2004, 31, 697-707. [CrossRef]

50. Arweiler, N.B.; Pietruska, M.; Pietruski, J.; Skurska, A.; Dolinska, E.; Heumann, C.; Auschill, T.M.; Sculen, A. Six-month results following treatment of aggressive periodontitis with antimicrobial photodynamic therapy or amoxicillin and metronidazole. Clin. Oral Investig. 2014, 18, 2129-2135. [CrossRef]

51. Yamamoto, T. Triggering role of focal infection in the induction of extra-palmoplantar lesions and pustulotic arthro-osteitis associated with palmoplantar pustulosis. In Recent Advances in Tonsils and Mucosal Barriers of the Upper Airways; Karger: Basel, Switzerland, 2011; Volume 72, pp. 89-92.

52. Mattila, K. Does periodontitis cause heart disease? Eur. Heart J. 2003, 24, 2079-2080. [CrossRef]

53. Jin, L.S.; Chiu, G.K.C.; Corbet, E.F. Are periodontal diseases risk factors for certain systemic disorders-what matters to medical practitioners? Hong Kong Med. J. 2003, 9, 31-37. [PubMed]

54. Konkel, J.E.; O’Boyle, C.; Krishnan, S. Distal consequences of oral inflammation are still discussed. Front. Immunol. 2019, 10, 1403. [CrossRef]

55. Hajishengallis, G. Periodontitis: From microbial immune subversion to systemic inflammation. Nat. Rev. Immunol. 2015, 15, 30-44. [CrossRef]

56. Fodor, A. Utilizing 'omics' tools to study the complex gut ecosystem. Adv. Exp. Med. Biol. 2014, 817, 25-38.

57. Saggioro, A. Leaky gut, microbiota, and cancer: An incoming hypothesis. J. Clin. Gastroenterol. 2014, 48, 62-66. [CrossRef] [PubMed]

58. McAllister, F.; Housseau, F.; Sears, C.L. Microbiota and immune responses in colon cancer: More to learn. Cancer J. 2014, 20, 232-236. [CrossRef] [PubMed]

59. Monsarrat, P.; Blaizot, A.; Kémoun, P.; Ravaud, P.; Nabet, C.; Sixou, M.; Vergnes, J.-N. Clinical research activity in periodontal medicine: A systematic mapping of trial registers. J. Clin. Periodontol. 2016, 43, 390-400. [CrossRef]

60. Bui, F.Q.; Almeida-da-Silva, C.L.C.; Huynh, B.; Trinh, A.; Liu, J.; Woodward, J.; Asadi, H.; Ojcius, D.M. Association between periodontal pathogens and systemic disease. Biomed. J. 2019, 42, 27-35. [CrossRef] [PubMed]

61. Williams, R.C.; Barnett, A.H.; Claffey, N.; Davis, M.; Gadsby, R.; Kellett, M.; Lip, G.Y.; Thackray, S. The potential impact of periodontal disease on general health: A consensus view. Curr. Med. Res. Opin. 2008, 24, 1635-1643. [CrossRef]

62. Grossi, S.G.; Genco, R.J. Periodontal disease and diabetes mellitus: A two-way relationship. Ann. Periodontol. $1998,3,52-61$. [CrossRef]

63. Saremi, A.; Nelson, R.G.; Tulloch-Reid, M.; Hanson, R.L.; Sievers, M.L.; Taylor, G.W.; Shlossman, M.; Bennett, P.H.; Genco, R.; Knowler, W.C. Periodontal disease and mortality in type 2 diabetes. Diabetes Care 2005, 28, 27-32. [CrossRef] [PubMed]

64. Azarpazhooh, A.; Leake, J. Systematic review of the association between respiratory diseases and oral health. J. Periodontol. 2006, 77, 1465-1482. [CrossRef] [PubMed] 
65. Brennan-Calanan, R.M.; Genco, R.J.; Wilding, G.E.; Hovey, K.M.; Trevisan, M.; Wactawski-Wende, J. Osteoporosis and oral infection: Independent risk factors for oral bone loss. J. Dent. Res. 2008, 87, 232-237. [CrossRef] [PubMed]

66. Kim, S.S.; Ruiz, V.E.; Carroll, J.D.; Moss, S.F. Helicobacter pylori in the pathogenesis of gastric cancer and gastric lymphoma. Cancer Lett. 2011, 305, 228-238. [CrossRef] [PubMed]

67. Dizdar, O.; Hayran, M.; Guven, D.C.; Yılmaz, T.B.; Taheri, S.; Akman, A.C.; Bilgin, E.; Hüseyin, B.; Berker, E. Increased cancer risk in patients with periodontitis. Curr. Med. Res. Opin. 2017, 33, 2195-2200. [CrossRef]

68. Michaud, D.S.; Fu, Z.; Shi, J.; Chung, M. Periodontal disease, tooth loss, and cancer risk. Epidemiol. Rev. 2017, 39, 49-58. [CrossRef]

69. Chung, M.; York, B.R.; Michaud, D.S. Oral health and cancer. Curr. Oral Health Rep. 2019, 6, 130-137. [CrossRef]

70. Güven, D.C.; Dizdar, Ö.; Akman, A.C.; Berker, E.; Yekedüz, E.; Ceylan, F.; Başpınar, B.; Akbıyık, İ.; Aktaş, B.Y.; Yüce, D.; et al. Evaluation of cancer risk in patients with periodontal diseases. Turk. J. Med. Sci. 2019, 49, 826-831. [CrossRef]

71. Printz, C. Study adds evidence to link between gum disease and cancer risk: Researchers observe connection with gastric, esophageal cancer. Cancer 2021, 127, 495-496. [CrossRef]

72. Hujoel, P.P.; Drangsholt, M.; Spiekerman, C.; Weiss, N.S. An exploration of the periodontitis-cancer association. Ann. Epidemiol. 2003, 13, 312-316. [CrossRef]

73. Ahn, J.; Segers, S.; Hayes, R.B. Periodontal disease, Porphyromonas gingivalis serum antibody levels and orodigestive cancer mortality. Carcinogenesis 2012, 33, 1055-1058. [CrossRef] [PubMed]

74. Kademani, D. Oral cancer. Mayo Clin. Proc. 2007, 82, 878-887. [CrossRef]

75. Szturz, P.; Vermorken, J.B. Treatment of elderly patients with squamous cell carcinoma of the head and neck. Front. Oncol. 2016, 6, 199. [CrossRef] [PubMed]

76. Warnakulasuriya, S. Global epidemiology of oral and oropharyngeal cancer. Oral Oncol. 2009, 45, 309-316. [CrossRef] [PubMed]

77. Dissanayaka, W.L.; Pitiyage, G.; Kumarasiri, P.V.; Liyanage, R.L.; Dias, K.D.; Tilakaratne, W.M. Clinical and histopathologic parameters in survival of oral squamous cell carcinoma. Oral Surg. Oral Med. Oral Pathol. Oral Radiol. 2012, 113, 518-525. [CrossRef] [PubMed]

78. Koontongkaew, S. The tumor microenvironment contribution to development, growth, invasion and metastasis of head and neck squamous cell carcinomas. J. Cancer 2013, 4, 66-83. [CrossRef] [PubMed]

79. Schultz, M. Rudolf Virchow. Emerg. Infect. Dis. 2008, 14, 1480-1481. [CrossRef]

80. Feller, L.L.; Khammissa, R.R.; Kramer, B.B.; Lemmer, J.J. Oral squamous cell carcinoma inrelation to field precancerisation: Pathobiology. Cancer Cell Int. 2013, 13, 31. [CrossRef]

81. Cavallo, F.; De Giovanni, C.; Nanni, P.; Forni, G.; Lollini, P.L. 2011: The immune hallmarks of cancer. Cancer Immunol. Immunother 2011, 60, 319-326. [CrossRef]

82. Bagan, J.; Sarrion, G.; Jimenez, Y. Oral cancer: Clinical features. Oral Oncol. 2010, 46, 414-417. [CrossRef]

83. Khurshid, Z.; Zafar, M.S.; Khan, R.S.; Najeeb, S.; Slowey, P.D.; Rehman, I.U. Role of salivary biomarkers in oral cancer detection. Adv. Clin. Chem. 2018, 86, 23-70.

84. Yang, C.Y.; Yeh, Y.M.; Yu, H.Y.; Chin, C.Y.; Hsu, C.W.; Liu, H.; Huang, P.J.; Hu, S.N.; Liao, C.T.; Chang, K.P.; et al. Oral microbiota community dynamics associated with oral squamous cell carcinoma staging. Front. Microbiol. 2018, 9, 862. [CrossRef] [PubMed]

85. Hasturk, H.; Kantarci, A. Activation and resolution of periodontal inflammation and its systemic impact. Periodontol. 2000. 2015, 69, 255-273. [CrossRef]

86. Meyer, M.S.; Joshipura, K.; Giovannucci, E.; Michaud, D.S. A review of the relationship between tooth loss, periodontal disease, and cancer. Cancer Causes Control 2008, 19, 895-907. [CrossRef] [PubMed]

87. Binder Gallimidi, A.; Fischman, S.; Revach, B.; Bulvik, R.; Maliutina, A.; Rubinstein, A.M.; Nussbaum, G.; Elkin, M. Periodontal pathogens Porphyromonas gingivalis and Fusobacterium nucleatum promote tumor progression in an oral-specific chemical carcinogenesis model. Oncotarget 2015, 6, 22613-22623. [CrossRef]

88. Zhang, L.; Liu, Y.; Zheng, H.J.; Zhang, C.P. The Oral Microbiota May Have Influence on Oral Cancer. Front. Cell. Infect. Microbiol. 2020, 9, 476. [CrossRef] [PubMed]

89. Tillonen, J.; Homann, N.; Rautio, M.; Jousimies-Somer, H.; Salaspuro, M. Role of yeasts in the salivary acetaldehyde production from ethanol among risk groups for ethanol-associated oral cavity cancer. Alcohol. Clin. Exp. Res. 1999, 23, 1409-1415. [CrossRef]

90. Loos, B.G. Systemic markers of inflammation in periodontitis. J. Periodontol. 2005, 76, 2106-2115. [CrossRef] [PubMed]

91. Nair, J.; Ohshima, H.; Nair, U.J.; Bartsch, H. Endogenous formation of nitrosamines and oxidative DNA-damaging agents in tobacco users. Crit. Rev. Toxicol. 1996, 26, 149-161. [CrossRef]

92. Franco, E.L.; Kowalski, L.P.; Oliveira, B.V.; Curado, M.P.; Pereira, R.N.; Silva, M.E.; Fava, A.S.; Torloni, H. Risk factors for oral cancer in Brazil: A case-control study. Int. J. Cancer 1989, 43, 992-1000. [CrossRef] [PubMed]

93. Zheng, T.; Boyle, P.; Hu, H.; Duan, J.; Jiang, P.; Ma, D.; Shui, L.; Niu, S.; Scully, C.; MacMahon, B. Dentition, oral hygiene, and risk of oral cancer: A case-control study in Beijing, People's Republic of China. Cancer Causes Control 1990, 1, 235-241. [CrossRef]

94. Marshall, J.R.; Graham, S.; Haughey, B.P.; Shedd, D.; O'Shea, R.; Brasure, J.; Wilkinson, G.S.; West, D. Smoking, alcohol, dentition and diet in the epidemiology of oral cancer. Oral Oncol. Eur. J. Cancer 1992, 28, 9-15. [CrossRef]

95. Wynder, E.L.; Bross, I.J.; Feldman, R.M. A study of the etiological factors in cancer of the mouth. Cancer 1957, 10, 1300-1323. [CrossRef]

96. Graham, S.; Dayal, H.; Rohrer, T.; Swanson, M.; Sultz, H.; Shedd, D.; Fischman, S. Dentition, diet, tobacco, and alcohol in the epidemiology of oral cancer. J. Natl. Cancer Inst. 1977, 59, 1611-1618. [CrossRef] [PubMed] 
97. Bundgaard, T.; Wildt, J.; Frydenberg, M.; Elbrond, O.; Nielsen, J.E. Case-control study of squamous cell cancer of the oral cavity in Denmark. Cancer Causes Control 1995, 6, 57-67. [CrossRef]

98. de Rezende, C.P.; Ramos, M.B.; Daguila, C.H.; Dedivitis, R.A.; Rapoport, A. Oral health changes in patients with oral and oropharyngeal cancer. Braz. J. Otorhinolaryngol. 2008, 74, 596-600. [CrossRef]

99. Guha, N.; Boffetta, P.; Filho, V.W.; Neto, J.E.; Shangina, O.; Zaridze, D.; Curado, M.P.; Koifman, S.; Matos, E.; Menezes, A.; et al. Oral health and risk of squamous cell carcinoma of the head and neck and esophagus: Results of two multicentric case-control studies. Am. J. Epidemiol. 2007, 166, 1159-1173. [CrossRef]

100. Hiraki, A.; Matsuo, K.; Suzuki, T.; Kawase, T.; Tajima, K. Teeth loss and risk of cancer at 14 common sites in Japanese. Cancer Epidemiol. Biomark. Prev. 2008, 17, 1222-1227. [CrossRef]

101. Mathur, R.; Singhavi, H.R.; Malik, A.; Nair, S.; Chaturvedi, P. Role of Poor Oral Hygiene in Causation of Oral Cancer-A Review of Literature. Indian J. Surg. Oncol. 2019, 10, 184-195. [CrossRef]

102. Inaba, H.; Sugita, H.; Kuboniwa, M.; Iwai, S.; Hamada, M.; Noda, T.; Morisaki, I.; Lamont, R.J.; Amano, A. Porphyromonas gingivalis promotes invasion of oral squamous cell carcinoma through induction of proMMP9 and its activation. Cell. Microbiol. 2014, 16, 131-145. [CrossRef] [PubMed]

103. Galvão-Moreira, L.V.; da Cruz, M.C.F.N. Oral microbiome, periodontitis and risk of head and neck cancer. Oral Oncol. 2016, 53, 17-19. [CrossRef]

104. Groeger, S.; Domann, E.; Gonzales, J.R.; Chakraborty, T.; Meyle, J. B7-H1 and B7-DC receptors of oral squamous carcinoma cells are upregulated by Porphyromonas gingivalis. Immunobiology 2011, 216, 1302-1310. [CrossRef] [PubMed]

105. Sepehr, A.; Kamangar, F.; Fahimi, S.; Saidi, F.; Abnet, C.C.; Dawsey, S.M. Poor oral health as a risk factor for esophageal squamous dysplasia in northeastern Iran. Anticancer Res. 2005, 25, 543-546.

106. de Martel, C.; Ferlay, J.; Franceschi, S.; Vignat, J.; Bray, F.; Forman, D.; Plummer, M. Global burden of cancers attributable to infections in 2008: A review and synthetic analysis. Lancet Oncol. 2012, 13, 607-615. [CrossRef]

107. Al-Hebshi, N.N.; Nasher, A.T.; Maryoud, M.Y.; Homeida, H.E.; Chen, T.; Idris, A.M.; Johnson, N.W. Inflammatory bacteriome featuring Fusobacterium nucleatum and Pseudomonas aeruginosa identified in association with oral squamous cell carcinoma. Sci. Rep. 2017, 7, 1834. [CrossRef] [PubMed]

108. Brennan, C.A.; Garrett, W.S. Fusobacterium nucleatum-symbiont, opportunist and oncobacterium. Nat. Rev. Microbiol. 2019, 17, 156-166. [CrossRef]

109. Yamamura, K.; Baba, Y.; Nakagawa, S.; Mima, K.; Miyake, K.; Nakamura, K.; Sawayama, H.; Kinoshita, K.; Ishimoto, T.; Iwatsuki, M.; et al. Human microbiome Fusobacterium nucleatum in esophageal cancer tissue is associated with prognosis. Clin. Cancer Res. 2016, 22, 5574-5581. [CrossRef]

110. Mysak, J.; Podzimek, S.; Sommerova, P.; Lyuya-Mi, Y.; Bartova, J.; Janatova, T.; Prochazkova, J.; Duskova, J. Porphyromonas gingivalis: Major periodontopathic pathogen overview. J. Immunol. Res. 2014, 2014, 476068. [CrossRef]

111. Peters, B.A.; Wu, J.; Pei, Z.; Yang, L.; Purdue, M.P.; Freedman, N.D.; Jacobs, E.J.; Gapstur, S.M.; Hayes, R.B.; Ahn, J. Oral microbiome composition reflects prospective risk for esophageal cancers. Cancer Res. 2017, 77, 6777-6787. [CrossRef]

112. Gao, S.G.; Yang, J.Q.; Ma, Z.K.; Yuan, X.; Zhao, C.; Wang, G.C.; Wei, H.; Feng, X.S.; Qi, Y.J. Preoperative serum immunoglobulin $\mathrm{G}$ and $\mathrm{A}$ antibodies to Porphyromonas gingivalis are potential serum biomarkers for the diagnosis and prognosis of esophageal squamous cell carcinoma. BMC Cancer 2018, 18, 17. [CrossRef] [PubMed]

113. Chen, W.; Alshaikh, A.; Kim, S.; Chun, C.; Mehrazarin, S.; Lee, J.; Lux, R.; Kim, R.H.; Shin, K.H.; Park, N.H.; et al. Porphyromonas gingivalis impairs oral epithelial barrier through targeting GRHL2. J. Dent. Res. 2019, 98, 1150-1158. [CrossRef] [PubMed]

114. Geng, F.; Wang, Q.; Li, C.; Liu, J.; Zhang, D.; Zhang, S.; Pan, Y. Identification of potential candidate genes of oral cancer in response to chronic infection with Porphyromonas gingivalis using bioinformatical analyses. Front. Oncol. 2019, 9, 91. [CrossRef]

115. Dye, B.A.; Choudhary, K.; Shea, S.; Papapanou, P.N. Serum antibodies to periodontal pathogens and markers of systemic inflammation. J. Clin. Periodontol. 2005, 32, 1189-1199. [CrossRef] [PubMed]

116. Gani, D.K.; Lakshmi, D.; Krishnan, R.; Emmadi, P. Evaluation of C-reactive protein and interleukin-6 in the peripheral blood of patients with chronic periodontitis. J. Indian Soc. Periodontol. 2009, 13, 69-74. [CrossRef]

117. Nagy, K.N.; Sonkodi, I.; Szoke, I.; Nagy, E.; Newman, H.N. The microflora associated with human oral carcinomas. Oral Oncol. 1998, 34, 304-308. [CrossRef]

118. Bergström, J. Tobacco smoking and chronic destructive periodontal disease. Odontology 2004, 92, 1-8. [CrossRef]

119. Hujoel, P.P.; Drangsholt, M.; Spiekerman, C.; DeRouen, T.A. Periodontitis-systemic disease associations in the presence of smoking-causal or coincidental? Periodontol. 2000 2002, 30, 51-60. [CrossRef]

120. Hung, H.C.; Colditz, G.; Joshipura, K.J. The association between tooth loss and the self-reported intake of selected CVD-related nutrients and foods among US women. Community Dent. Oral Epidemiol. 2005, 33, 167-173. [CrossRef] 